\title{
Determining the specific status of the Iberian sturgeons by means genetic analyses of old specimens
}

\author{
Francisca Robles ${ }^{1 *}$, Belén Cano-Roldán ${ }^{1}$, Carmelo Ruiz Rejón ${ }^{1}$, Luís Javier Martínez-González ${ }^{2}$, \\ María Jesús Álvarez-Cubero ${ }^{2}$, José Antonio Lorente ${ }^{2}$, José Antonio Riquelme Cantal ${ }^{3}$, Pedro Aguayo \\ de Hoyos ${ }^{4}$, Javier Carrasco Rus ${ }^{4}$, Miguel Cortés Sánchez ${ }^{5}$, María Dolores Simón Vallejo ${ }^{6}$, Manuel Ruiz \\ Rejón ${ }^{1}$, Roberto de la Herrán ${ }^{1}$

\footnotetext{
${ }^{2}$ Centro Pfizer, Universidad de Granada, Junta de Andalucía de Genómica e Investigación Oncológica, Centro de Investigación Biomédica, Av. del Conocimiento s/n, Armilla, Granada, Spain;

${ }^{3}$ Consejería de Cultura, Junta de Andalucía, Sevilla, Spain;

${ }^{4}$ Departamento de Prehistoria y Arqueología. Facultad de Filosofía y Letras, Universidad de Granada, Granada, Spain;

${ }^{5}$ Faculdade de Ciências Humanas e Sociais, Universidade do Algarve, Faro, Portugal;

${ }^{6}$ Fundación Cueva de Nerja, Malaga, Spain.

Email: frobles@ugr.es
} \\ ${ }^{1}$ Departamento de Genética, Facultad de Ciencias, Universidad de Granada, Granada, Spain;
}

Received 5 April 2010; revised 22 April 2010; accepted 11 May 2010.

\begin{abstract}
To clarify the species status of sturgeon from rivers of the Iberian Peninsula, eight molecular markers (4 nuclear and 4 mitochondrial) have been analysed in different specimens from historical museum samples and prehistoric samples from archaeological sites. These analyses indicate that one of these specimens (UGP captured in the Guadalquivir River in the 19th century) is $A$. sturio, based on all the eight molecular markers, four of them used from the first time in this study. In previous analyses based on 5 genetic markers, our group assigned two specimens captured in this river in the 1970-80s (EBD8173 and EBD8401) to the species $A$. naccarii, suggesting the presence of this species in the Iberian Peninsula. In this work, this conclusion is drawn after successfully obtaining a mitochondrial marker in a very old scute from a prehistoric site (Acinipo, about 1500 BC, from the Guadalquivir River basin). On the other hand, in the specimen EBD8174 captured in the Guadalquivir in 1975, we have obtained two new mitochondrial markers confirming that it can be considered $A$. sturio for all the mitochondrial markers, but nuclear ones identify it as $A$. naccarii. Finally, two very old samples (Nerja E-VI and Nerja N/62-63) were not successfully characterized by any molecular markers. Some aspects and consequences of our results are discussed, such as the origin of the "mosaic" specimen EBD8174 and, above all, the native status of $A$. naccarii in historic and prehistoric times in the southern Iberian Peninsula.
\end{abstract}

Keywords: Iberian Sturgeons; $A$. naccarii; A. sturio; Ancient DNA; Genetic Identification; Molecular Markers

\section{INTRODUCTION}

The identification of sturgeon species inhabiting a certain geographical region has interest not only from the basic scientific standpoint but also for the conservation and recovery of this group of ancient fish so important from the evolutionary as well as the economic perspective [1]. Thus, the specific status of the Iberian Peninsula sturgeons is a debatable matter because, bearing in mind that they are currently almost extinct, it becomes necessary to analyse old museum specimens and even archaeological remains. In this sense, during the second half of the 20th century, it was traditionally considered that in the seas and southern rivers of Western Europe and, more concretely, in the southern Iberian Peninsula, there was only one sturgeon species, Acipenser sturio (Linnaeus 1758). However, from end of last century, the idea arose that until recently at least two species could have coexisted. In fact, based on morphologic and mainly genetic studies (including mitochondrial and nuclear markers) of old museum specimens of sturgeons from this region, it has been shown [2-4] that, in addition to specimens belonging to $A$. sturio, it is possible to find specimens belonging to another species, A. naccarii (Bonaparte 1836). This situation had been previously proposed by different authors who historically, although forgotten, cited A. naccarii in the Iberian Pen- 
insula [5-13]. All these results would indicate that, in recent historical times, this latter species (A. naccarii), until now considered only endemic to the Adriatic region, would also have lived in rivers of the Iberian Peninsula.

However, these results have been questioned partly by other studies, which have not provided data to indicate the presence of the species A. naccarii in this region [14-16]. Finally, recently Ludwig et al. [17] studying the mitochondrial region control in five scutes of sturgeons from archaeological locations of historical times in the Iberian Peninsula, have recently found only mitochondrial haplotypes of A. sturio. Therefore, it becomes necessary to continue delving into the analysis of this issue.

In this work, our group, which has contributed to opening this new vision of the distribution of sturgeons in Southern Europe (i.e. the coexistence of A.naccarii with $A$. sturio), analyses and discusses the attempts to obtain eight molecular markers (mitochondrial and nuclear) in seven old specimens of historic and prehistoric times in southern Spain. These molecular markers are compared in several sturgeon species. Thus, the results previously reported by our group have been corroborated in four historical specimens. In addition, we have tried to clarify the specific status of three new sturgeon samples from archaeological sites. Emphasis is placed mainly on the positive results for one of these samples, in a scute of a very old specimen dating from $1500 \mathrm{BC}$, which again verifies the presence of the species $A$. naccarii in this region.

\section{MATERIALS AND METHODS}

\subsection{Samples}

In this work, DNA was extracted from seven old sturgeon specimens from the southern Iberian Peninsula. Four of the specimens analysed had been captured in the Guadalquivir River, EBD8173, EBD8401, EBD8174 and UGP. Three of them (labelled EBD), captured in the 1970-80s, are conserved in the Biological Station of Doñana (Spain). The samples EBD8173 and EBD8401 are preserved in ethanol, whereas the EBD8174 is a dry skin. The fourth sample (labelled UGP) is a skin conserved in the Department of Biology Animal of the University of Granada and was also captured in the Guadalquivir River (19th century).

Additionally, three prehistoric samples are analysed for first time. One of them corresponds to a scute from $1500 \mathrm{BC}$ which was found in the Acinipo archaeological deposit (Ronda, Malaga, Spain) (Figure 1). The archaeological deposit of Ronda la Vieja (called Acinipo, the name of the Roman city built on this site; [18]) is located in the depression of Ronda, $20 \mathrm{~km}$ from the city. The site

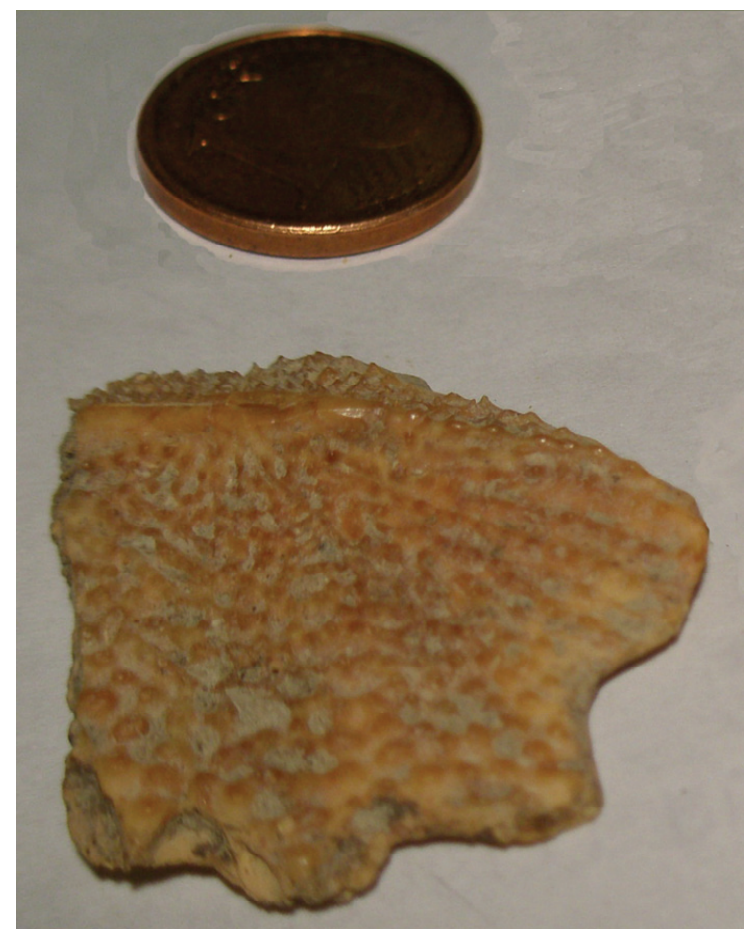

Figure 1. Scute dated in $1500 \mathrm{BC}$ found in the archaeological deposit of Acinipo (Ronda, Malaga, Spain).

is situated on a large limestone plateau, which provides a strategic view of the surrounding territory and provides communication with other areas, including the countryside of the Guadalquivir River. The bony sample of sturgeon analysed corresponds to the archaeological phase Acinipo III [19], prior to the Phoenician colonization around the second half of the II millennium B.C. Although it is difficult to assign its origin to the Guadalquivir River, the dates and the zone where it has been found would indicate its origin from this river. Finally, an attempt was made to extract DNA and amplify the different molecular markers from two very old scutes of sturgeons found at another prehistoric deposit (Cave of Nerja, Malaga, Spain). The Cave of Nerja has a long ichthyoarchaeological record of the excavations made basically in the room of the Vestíbulo [20] on the stratum VII (about 12,000 years old). This level is correlated with Magdalenian occupation in the cave [21].

\subsection{DNA Extraction}

The extraction and purification of DNA was carried out using ancient DNA techniques and according to the protocol described in Martínez-Espín et al. [22]. The first step consisted of cleaning the tissue samples in a polymethacrylate (PMMA) box. A miniature Dremel drill was used to eliminate any polluting agents adhering to the surface. Then, the tissue samples were pulverized in liquid nitrogen using a Freezer Mill. After pulverization, 
the powdered sample was transferred to a sterile $15 \mathrm{ml}$ conical polypropylene tube.

To improve DNA recovery, in older samples (the scute from Acinipo and the two scutes from Nerja), we made some changes in the protocols. For these three samples, a protocol was adapted for demineralization of skeletal remains frequently used in mommies and historical identification $[23,24]$. To minimize the possibility of contamination by contemporary DNA of extraneous sources, these samples were extracted in the minimal-humanremains laboratory, where an animal sample had never before been extracted. Here, possible contamination was eliminated from the old samples. Only one specimen was cleaned and processed at the same time and a negative control was included with the analysis of each specimen. After adding demineralization buffer, the samples were incubated on an orbital shaker at $56^{\circ} \mathrm{C}$ for 20-30 h. The tubes were angled during agitation to ensure thorough mixing. At the beginning of the extraction, we first added $50 \mu \mathrm{l}$ of proteinase $\mathrm{K}(20 \mathrm{mg} / \mathrm{ml})$ and 25 $\mu \mathrm{l}$ again $18 \mathrm{~h}$ later. The extracts were purified using sterile water washes in Microcon YM-30 Millipore centrifugal filter units; in the other samples, Microcon YM-100 was used. As a final point, the concentrator was discarded, and $200 \mu 1$ of the purified DNA were obtained. In this case, many inhibitors were also obtained owing to the fact that tissue is adsorbed into a mineral matrix, after the death of the animal. The following step was the purification with the GENECLEAN ${ }^{\circledR}$ (BIO 101) for Ancient DNA Kit (using the recommended protocol). To guarantee the absence of inhibitor, the Quantifiler ${ }^{\mathbb{B}}$ kit for 7500 Real-Time PCR (Applied Biosystems) was used. The Internal Positive Control detectors indicated the absence of PCR inhibitor in all samples.

\subsection{Amplification, Cloning, and Sequencing of Molecular Markers}

For each specimen an effort was made to characterize the following genetic markers: 1) four nuclear markers corresponding to two satellite-DNA families: the family HindIII [25] and the family PstI [26]; non-transcribed sequences of $5 \mathrm{~S}$ ribosomal gene (NTS) [27] and 230 base pairs from nuclear DNA flanking the microsatellite Aox-23 [28]. 2) four mitochondrial markers corresponding to two fragments of the cytochrome $b$ gene of $212 \mathrm{bp}$ and $265 \mathrm{bp}$, respectively [29,30], one fragment of $210 \mathrm{bp}$ corresponding to the mitochondrial region control, $\mathrm{d}$-loop, [30], and one fragment of the $12 \mathrm{~S}$ ribosomal gene of $139 \mathrm{bp}$ [16]. In each case, the PCR reactions were carried out with the amplification conditions described in each of the references.

Each marker was cloned using the vector TOPO TA (TOPO TA Cloning ${ }^{\circledR}$ kit PCR $^{\circledR} 2.1$ ) and were used to transform the cells DH5 $\alpha$ of E. coli, according to the supplier recommendations (Invitrogen Carlsbad, CA, USA).

Recombinant plasmids were sequenced on both strands using Big Dye ${ }^{\circledR}$ Terminator Cycle Sequencing Kit (Applied Biosystems) and T7 and M13 primers in an ABI Prims ${ }^{\circledR}$ 3100-Avant Genetic Analyzer DNA Sequencer (Applied Biosystems).

\subsection{Sequence Analysis}

Multiples alignments of sequences obtained from the samples and reference sequences from GenBank database were performed using ClustalX software [31]. Phylogenetic and molecular evolutionary analyses were conducted using MEGA version 4 [32]. Sequence divergences were calculated according to the Jukes-Cantor method and distance trees produced by UPGMA [33] and the neighbour-joining method [34].

\section{RESULTS AND DISCUSSION}

The (Table 1) presents a summary for all the seven sturgeon specimens from Iberian Peninsula analysed for different molecular markers. This table includes the data obtained in this new study, completed with the data from previous analyses made by us.

The specimen UGP (Table 1) had previously been analysed for four markers (HindIII and Pst I satellite DNA family, 212-bp cytochrome $\mathrm{b}$ and $12 \mathrm{~S}$ mitochondrial gene) and catalogued as A. sturio [4]. Considering nuclear markers, Garrido-Ramos et al. [4] analysed this specimen for the HindIII satellite DNA family, showing the lack of this repetitive sequence in its genome (its absence is characteristic of the species A. sturio; [35]) In the same study, these researchers showed that the sequences corresponding to PstI satellite DNA family analysed for this specimen UGP were grouped, in a phylogenetic tree, together with the sequences of $A$. sturio.

Now, nine clones have been sequenced for non-transcribed sequences of the $5 \mathrm{~S}$ ribosomal nuclear genes (NTS), and their sequences were aligned with NTS ribosomal genes from other sturgeon species (Figure 2). Characteristic positions for A. sturio and A. oxyrinchus are present in the sequences isolated from UGP. Thus, in a phylogenetic tree based in genetics distances, all sequences belonging to this sample were grouped together with the NTS sequences of $A$. sturio (Figure 2).

Additionally, a new nuclear marker Aox23 locus [28] was amplified in this specimen. The sequence found, when compared with sequences of $A$. sturio and $A$. oxyrinchus taken from GenBank, proved similar to those of A. sturio (data not shown). 
Table 1. Summary of sturgeon specimens analysed.

\begin{tabular}{|c|c|c|c|c|c|c|c|c|c|c|c|c|}
\hline \multirow[b]{2}{*}{ Specimen } & \multirow[b]{2}{*}{$\begin{array}{l}\text { Provenance } \\
\text { (year of catch) }\end{array}$} & \multirow[b]{2}{*}{$\begin{array}{l}\text { Sampling location } \\
\text { (preservation) }\end{array}$} & \multirow[b]{2}{*}{$\begin{array}{l}\text { Traditional } \\
\text { Classification }\end{array}$} & \multicolumn{8}{|c|}{ Molecular markers, Number of sequences analysed and Accession Number } & \multirow[b]{2}{*}{ Molecular status } \\
\hline & & & & HindIII & $P_{s t \mathrm{I}}$ & NTS & Aox23 & $\begin{array}{l}\text { 212-bp } \\
\text { Cyt b }\end{array}$ & $\begin{array}{l}\text { 265-bp } \\
\text { Cyt b }\end{array}$ & d-loop & $\begin{array}{c}12 \mathrm{~S} \\
\text { mitochondrial } \\
\text { gene }\end{array}$ & \\
\hline UGP & $\begin{array}{l}\text { Guadalquivir } \\
\text { river } \\
\text { (nineteenth } \\
\text { century) }\end{array}$ & $\begin{array}{l}\text { Museum of the Animal } \\
\text { Biology Department. } \\
\text { Facultad de Ciencias. Univ } \\
\text { of Granada, Spain (stuffed) }\end{array}$ & A.sturio & np & $\begin{array}{c}6 \\
\text { FN256417 } \\
\text { to } \\
\text { FN256422 }\end{array}$ & $\begin{array}{c}9^{*} \\
\text { FN256408 } \\
\text { to } \\
\text { FN256416 }\end{array}$ & $\begin{array}{c}9^{*} \\
\text { FN256399 } \\
\text { to } \\
\text { FN256407 }\end{array}$ & FN256388 & $\begin{array}{c}* \\
\text { FN256392 }\end{array}$ & $\begin{array}{c}* \\
\text { FN } 256381\end{array}$ & $\mathrm{FN} 256367$ & A.sturio \\
\hline EBD8173 & $\begin{array}{c}\text { Guadalquivir } \\
\text { river, Alcalá } \\
\text { del Río. } \\
\text { Seville, Spain } \\
\text { (1974) }\end{array}$ & $\begin{array}{l}\text { Doñana Biological Station, } \\
\text { Seville, Spain (ethanol) }\end{array}$ & A.sturio & Z50744 & $\begin{array}{c}4 \\
\text { AJ543450, } \\
\text { AJ543451, } \\
\text { AJ543458, } \\
\text { AJ543459 }\end{array}$ & $\begin{array}{c}2 \\
\text { AJ543472, } \\
\text { AJ543473 }\end{array}$ & - & AJ543488 & - & - & AJ543480 & A.naccarii \\
\hline EBD8401 & $\begin{array}{l}\text { Guadalquivir } \\
\text { river, Coria del } \\
\text { Río, Seville, } \\
\text { Spain (1981) }\end{array}$ & $\begin{array}{l}\text { Doñana Biological Station, } \\
\text { Seville, Spain (ethanol) }\end{array}$ & A.sturio & $\begin{array}{c}2 \\
\text { AJ543464, } \\
\text { AJ543465 }\end{array}$ & $\begin{array}{c}6 \\
\text { AJ543452 } \\
\text { to } \\
\text { AJ543457 }\end{array}$ & $\begin{array}{c}6 \\
\text { AJ543466 } \\
\text { to } \\
\text { AJ543471 }\end{array}$ & - & AJ543485 & - & - & AJ543482 & A.naccarii \\
\hline EBD8174 & $\begin{array}{c}\text { Guadalquivir } \\
\text { river, Alcalá } \\
\text { del Río. } \\
\text { Seville, Spain } \\
(1975)\end{array}$ & $\begin{array}{l}\text { Doñana Biological Station, } \\
\text { Seville, Spain (stuffed) }\end{array}$ & A.sturio & AJ543463 & $\begin{array}{c}3 \\
\text { AJ543460 } \\
\text { to } \\
\text { AJ543462 }\end{array}$ & $\begin{array}{c}5 \\
\text { AJ543474 } \\
\text { to } \\
\text { AJ543478 }\end{array}$ & - & AJ543486 & $\begin{array}{c}* \\
\text { FN256395 }\end{array}$ & $\begin{array}{c}* \\
\text { FN256386 }\end{array}$ & AJ543479 & $\begin{array}{c}\text { A.naccarii (nuclear) } \\
\text { A.sturio } \\
\text { (mitochondrial) }\end{array}$ \\
\hline Acinipo & $\begin{array}{l}\text { Archaeological } \\
\text { Deposit of } \\
\text { Ronda la Vieja } \\
\text { (Ronda, } \\
\text { Malaga, Spain) }\end{array}$ & $\begin{array}{l}\text { Municipal Archaeological } \\
\text { Museum of Ronda, } \\
\text { Malaga, Spain }\end{array}$ & $?$ & - & - & - & - & - & - & - & $\begin{array}{c}* \\
\text { FN256368 }\end{array}$ & A.naccarii \\
\hline $\begin{array}{l}\text { Nerja E- } \\
\text { VI } 1963\end{array}$ & $\begin{array}{l}\text { Cave of Nerja } \\
\text { (Malaga, } \\
\text { Spain) }\end{array}$ & $\begin{array}{l}\text { Provincial Archaeological } \\
\text { Museum of Malaga, Spain }\end{array}$ & $?$ & - & - & - & - & - & - & - & - & $?$ \\
\hline $\begin{array}{l}\text { Nerja } \\
\text { N/62-63 } \\
36 / \mathrm{VII} \\
\text { Caja 25 }\end{array}$ & $\begin{array}{l}\text { Cave of Nerja } \\
\text { (Malaga, } \\
\text { Spain) }\end{array}$ & $\begin{array}{l}\text { Provincial Archaeological } \\
\text { Museum of Malaga, Spain }\end{array}$ & $?$ & - & - & - & - & - & - & - & - & $?$ \\
\hline
\end{tabular}

List of sturgeon specimens analysed, their current specific status and the results for the markers analysed in each specimen and the number of units sequenced (with their accession number) for each nuclear repetitive marker or the number of mitochondrial clones sequenced for each mitochondrial marker. np: not present; na: not amplified; the asterisk (*) shows the sequences found in this study; question mark (?) indicates unknown Traditional Classification and/or Molecular status.

With respect to mitochondrial markers, GarridoRamos et al. [4] analysed in this specimen the fragments of the mitochondrial DNA 212-bp cytochrome $b$ and $12 \mathrm{~S}$ gene and considered UGP as $A$. sturio. In the present work, two new mitochondrial markers have been amplified for this sample (265-bp cytochrome b and d-loop). It was found that all diagnostic positions for these markers correspond to the species A. sturio (Figures 3(a) and (b)).

Therefore, the results of eight nuclear and mitochondrial markers confirm the classification of this sample (UGP) as A. sturio. This affirmation is not surprising if we bear in mind, as mentioned in the Introduction, that the species $A$. sturio has been broadly described in most of rivers of the Iberian Peninsula.

On the other hand, previous molecular analyses carried out by our group in three samples from the Biological Station of Doñana (Table 1), identified two of them, EBD8173 and EBD8401, as A. naccarii, based both on the mitochondrial and on the nuclear markers [2-4]. Thus, the samples EBD8173 and EBD8401 have the HindIII satellite DNA family in their genome. This satellite DNA, as commented above, is absent in the A. sturio genome [2].
The presence of this repetitive sequence means that these two samples cannot be assigned to A. sturio, the only species that had previously been considered to live in the rivers of the Iberian Peninsula. Additional results using the markers PstI satellite DNA, non-transcribed sequences of $5 \mathrm{~S}$ ribosomal gene (Figure 2), 212-bp cytochrome $\mathrm{b}$ and $12 \mathrm{~S}$ mitochondrial gene (Figures 3(a) and 4) confirmed that EBD8173 and EBD8401 belong to A. naccarii $[3,4]$.

However, the sample EBD8174 (Table 1) is a special specimen from the genetic perspective. For all the nuclear markers analysed to date, this sample EBD8174 cannot be assigned to A. sturio but to A. naccarii. The presence of HindIII satellite DNA family and the fact that all the sequences corresponding to the nuclear markers (the HindIII itself and satellite PstI and NTS) are not grouped with $A$. sturio but with $A$. naccarii are indicative of this fact $[3,4]$. However, previous mitochondrial DNA studies using 212-bp cytochrome b and $12 \mathrm{~S}$ mitochondrial gene DNA markers $[3,15,16]$, conclude that, in this specimen, mitochondrial DNA markers are similar to $A$. sturio.

Thus, the results of nuclear and mitochondrial DNA are contradictory in this specimen because, the nuclear 


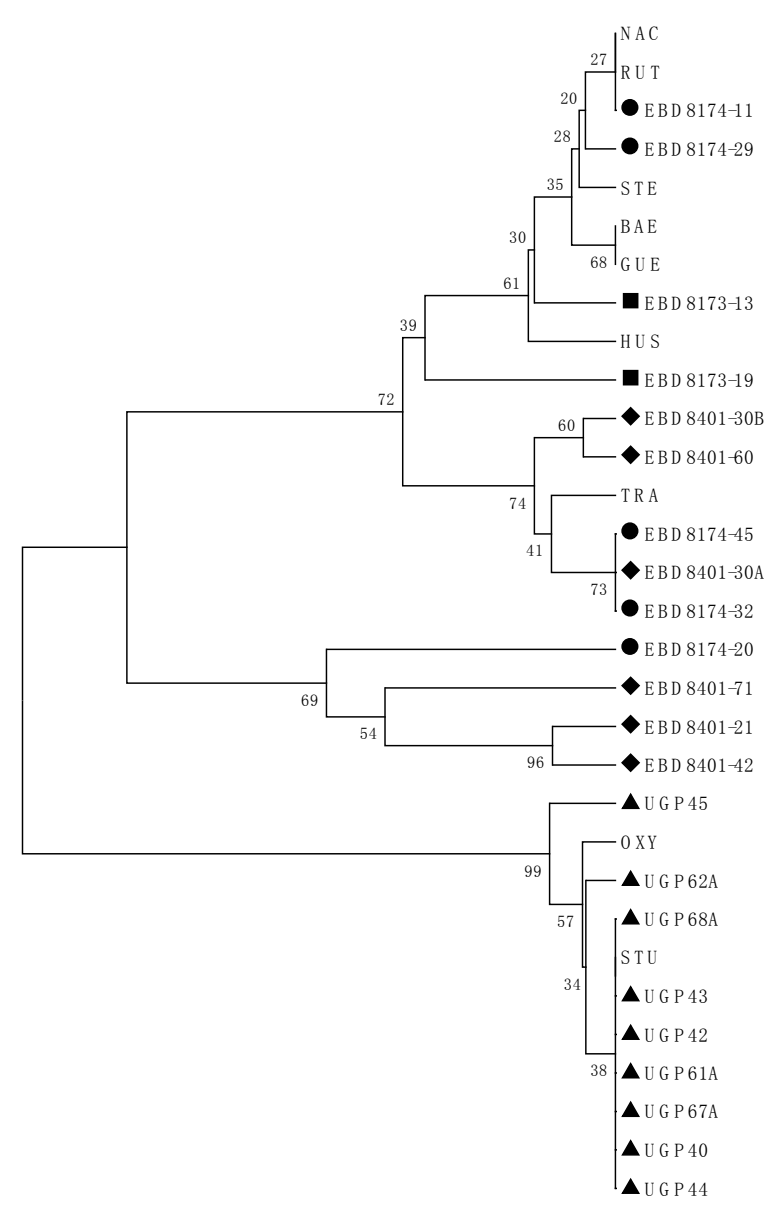

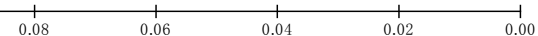

Figure 2. UPGMA tree based on NTS sequences of 5S ribosomal nuclear genes. UPGMA tree based on NTS sequences and Juckes Cantor distances calculated in MEGA 4. The tree shows the close relationships between the 9 NTS sequences from UGP ( $\boldsymbol{\Delta}$ ) specimen and NTS sequences of $A$. sturio (STU AJ550044) and A. oxyrinchus (OXY AJ555397), and between the 13 NTS sequences from the three EBD specimens -EBD8173 (•), EBD8174 (•) and EBD8401 ( $\bullet$ )- and NTS sequences of $A$. naccarii (NAC AJ550039) and other sturgeon species as $A$. transmontanus (TRA AJ555360), A. baerii (BAE AJ555351), A. gueldenstaedtii (GUE AJ555353), A. stellatus (STE AJ555385), Huso huso (HUS AJ555358) and $A$. ruthenus (RUT AJ555393). The code name species and the accession number are show into parenthesis. Numbers indicate bootstrap support for each node (10000 replicates).

DNA markers indicate its assignment to $A$. naccarii but mitochondrial DNA markers show identities to $A$. sturio. To confirm this situation, we analysed two new mitochondrial markers, 265-bp cytochrome b and d-loop (Figures 3(a) and (b)). And the results coincided with previous ones, demonstrating that this sample corresponds to A. sturio for all mitochondrial markers. In fact, in the mitochondrial sequences analysed in this study (265-bp cytochrome b and d-loop), we found positions fixed with those of the species $A$. sturio.

Thus, the specimen EBD8174 could be considered a "mosaic" sturgeon: having nuclear characteristics of $A$. naccarii but mitochondrial markers of A. sturio. Hybridization or introgression processes between $A$. sturio and $A$. naccarii could explain this phenomenon. In sturgeons, genetic evidence of hybridisation phenomena between sympatric sturgeon species has been shown for example in Arefjev [36], and more recently between $A$. ruthenus and A. baerii in the Danube River [37].

Also, similar introgression processes have been described previously in the Adriatic region (A. gueldenstaedtii introgressed into the $A$. naccarii) [38] and in the population of the Baltic Sea of A. sturio (A. oxyrinchus introgressed into the A. sturio; [39]).

Finally, we have tried to clarify the specific status of three samples from archaeological sites (Table 1). Two of these samples (about 12,000 years old found at an older prehistoric settlement, the Cave of Nerja) were not successfully analysed. Unfortunately, none of the markers used could be characterized for these samples. However, we succeeded in amplifying a fragment of the $12 \mathrm{~S}$ mitochondrial gene from the prehistoric scute (Ronda, Malaga, of about 3500 years of antiquity) found at the archaeological site of Acinipo (Table 1). These results are tentative because the first samples were very old and it was difficult to extract enough quality DNA to amplify the molecular markers. However, in previous studies some samples with similar antiquity at Acinipo, have been used successfully in species identification $[17,40]$.

The 12S mitochondrial gene obtained from the Acinipo sample was compared with other $12 \mathrm{~S}$ sequences from different species of sturgeons in the GeneBank database. The diagnostic positions for this marker did not coincide with $A$. sturio, ruling out its assignment to this species (Figure 4). In fact, all diagnostic sites coincided with $A$. naccarii, although they are not exclusive of this species, sharing them with other sturgeon species such as $A$. gueldenstaedtii, A. baerii, A. persicus and $A$. nudiventris with a distribution far away from the Iberian Peninsula. Thus, in a phylogenetic tree, based on genetic distances, the sequence from the Acinipo scute is grouped with the sequences from A. naccarii (Figure 5).

\section{CONCLUSIONS}

The nuclear and mitochondrial markers show that the specimens EBD8173 and EBD8401 belong to the species $A$. naccarii, and the sample UGP to $A$. sturio. The specimen EBD8174, using mitochondrial markers can be catalogued as A. sturio, or as A. naccarii according to nuclear markers. Hybridization or introgression proc- 
esses between $A$. sturio and A. naccarii, could explain this phenomenon, common in sturgeons in these species. On the other hand, we were able to analyse the $12 \mathrm{~S}$ mitochondrial marker for the ACINIPO sample (3500 years old) demonstrating that it belongs to species $A$. naccarii. These analyses provide insights into the existence of specimens belonging to A. naccarii in the southern Ibe- rian Peninsula in historic (EBDs samples) and prehistoric (ACINIPO) times. Thus, our analyses confirm old references mentioning the presence of $A$. naccarii in the Iberian Peninsula [5-13]. Therefore, although A. naccarii is currently considered endemic of the Adriatic Sea, in the past it could have had a broader distribution area, extending to the Iberian Peninsula, including the Gua-
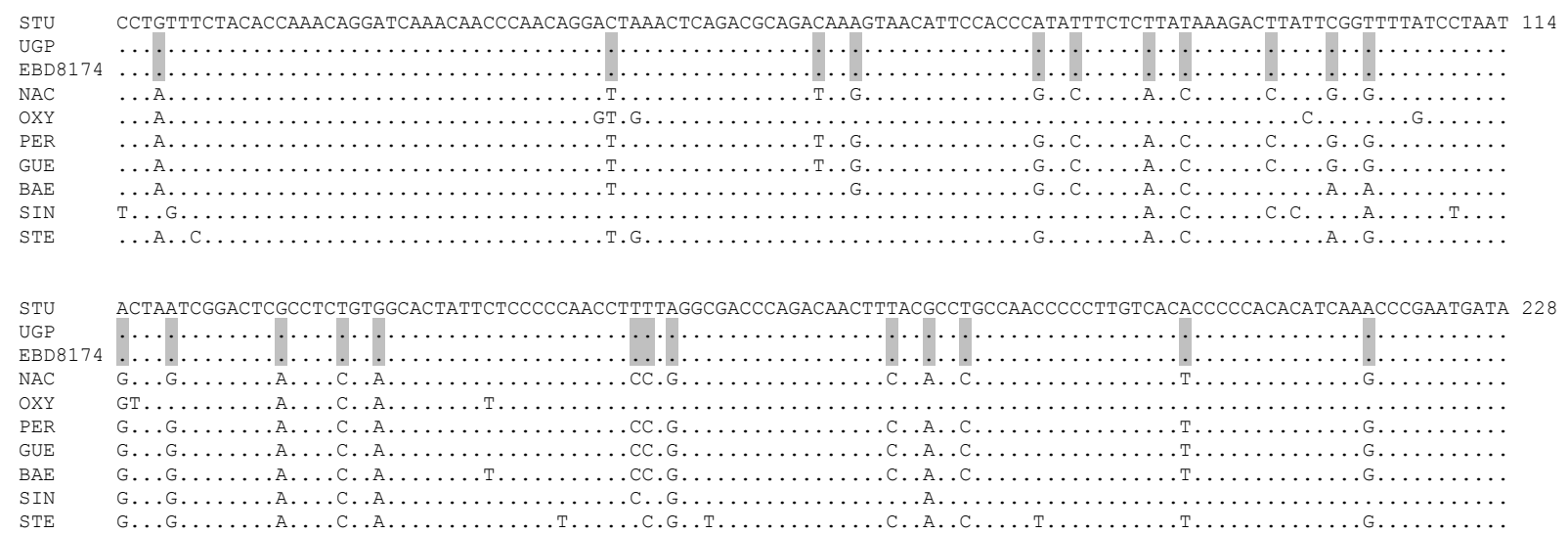

(a)
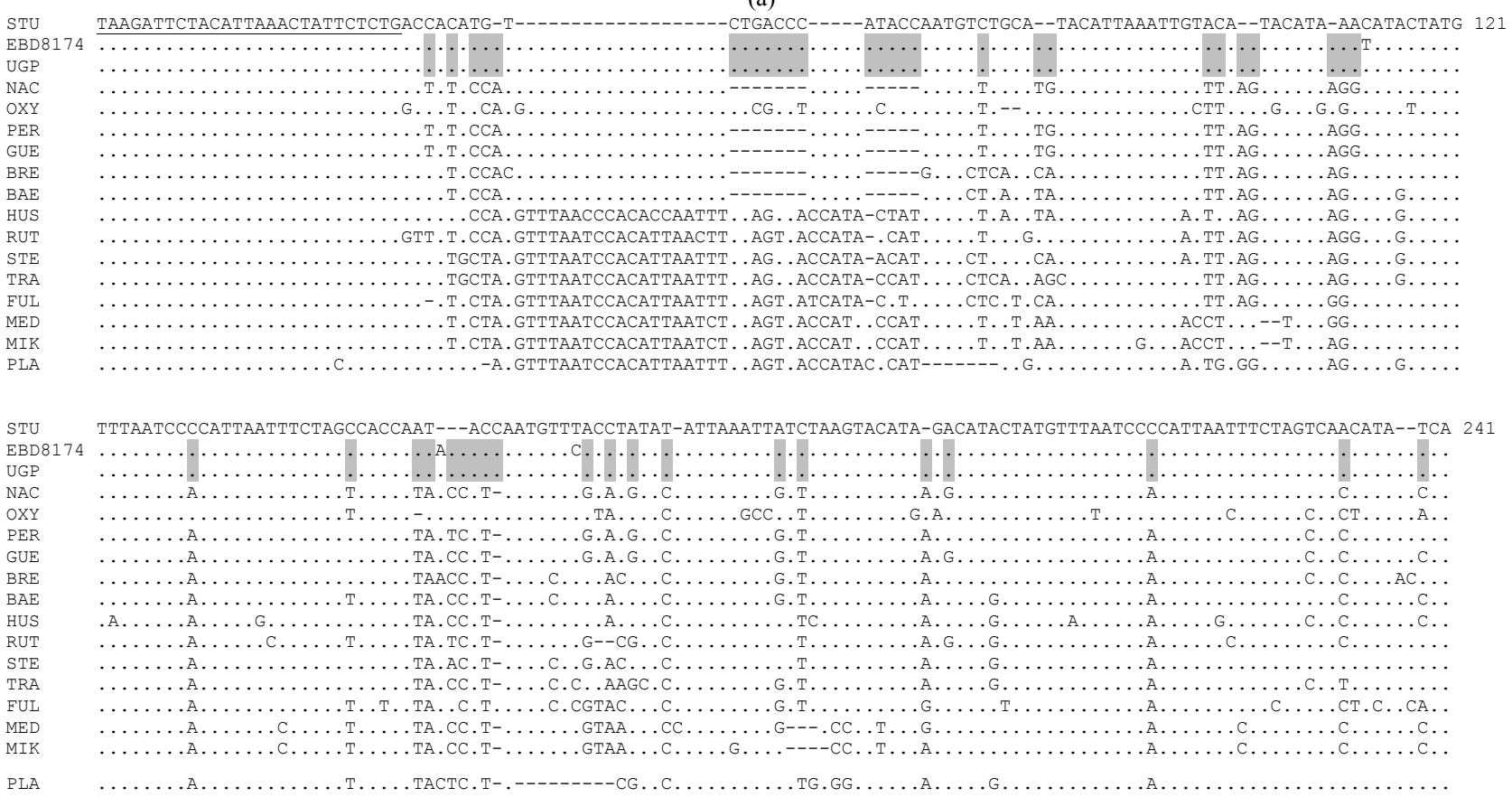

(b)

Figure 3. (a) Alignment of sequences of a 265-bp cytochrome b fragment. Multiple alignment of the sequences of a 265-bp cytochrome-b fragment from UGP and EBD8174, respectively. They are compared with the same mitochondrial DNA region from $A$. sturio (STU AJ245839), A. naccarii (NAC AJ245834), A. oxyrinchus (OXY AJ245838), A. persicus (PER AJ245835), A. gueldenstaedtii (GUE AJ245827), A. baerii (BAE AJ245825), A. sinensis (SIN AJ252186), A. stellatus (STE AY846686). The grey boxes show the diagnostic sites used in the analysis. The primer sequence is not used in the alignment; (b) Alignment of partial d-loop sequences. Multiple alignment of the sequences of the d-loop from EBD8174 and UGP, respectively. These are compared with sequences of the same mitochondrial DNA region from 15 different species of sturgeon: A. sturio (STU AJ428274), A. naccarii (NAC AJ275199), A. oxyrinchus (OXY AJ249670), A. persicus (PER AJ275205), A. gueldenstaedtii (GUE AJ249668), A. brevirostrum (BRE AJ275194), A. baerii (BAE AJ249660), H. huso (HUS AJ249675), A. ruthenus (RUT AJ249671), A. stellatus (STE AJ249672), A. transmontanus (TRA AJ249674), A. fulvescens (FUL AJ249661), A. medirostris (MED AJ275188), A. mikadoi (MIK AJ275189) and S. platorynchus (PLA AJ249676). The grey boxes show the diagnostic sites used in the analysis. The partial tRNA ${ }^{\text {Pro }}$ sequences are underlined. The alignment does not show the primer sequence. 


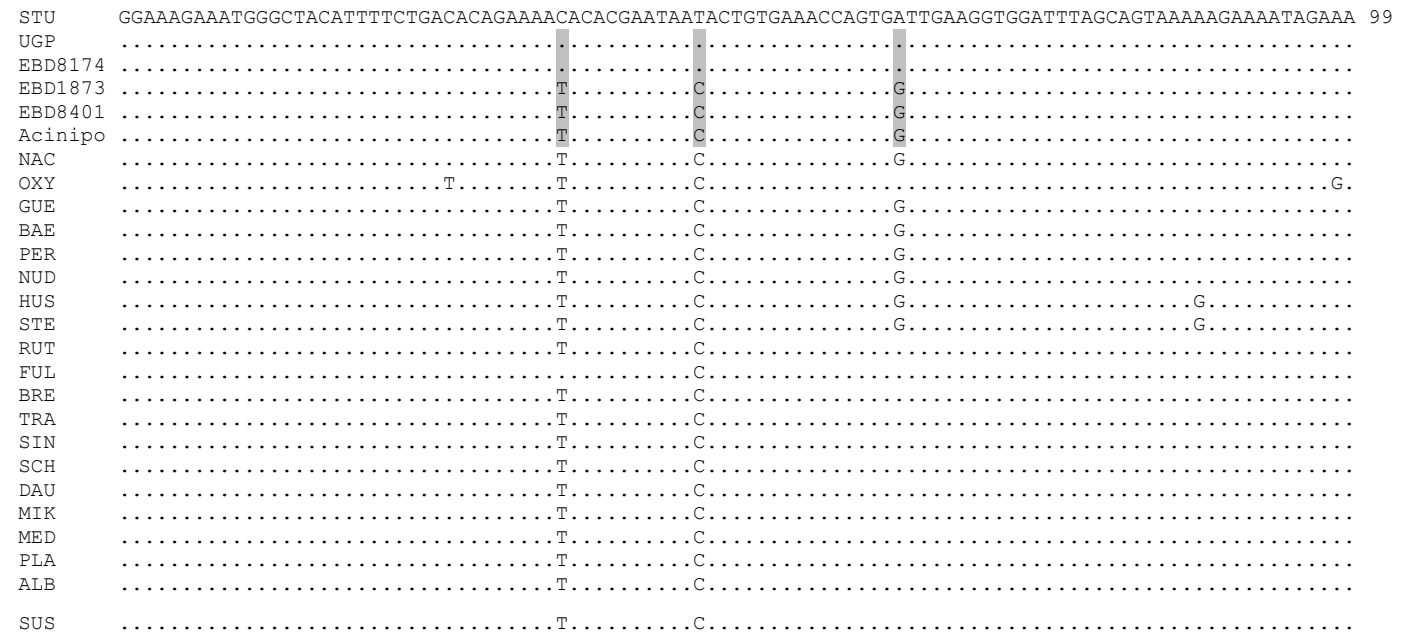

Figure 4. Alignment of sequences of $12 \mathrm{~S}$ mitochondrial gene from Acinipo. Multiple alignment of sequences of $12 \mathrm{~S}$ mitochondrial gene from Acinipo. These are compared with the same mitochondrial-DNA region from the three EBD and UGP specimens, $A$. sturio (STU AJ549115), A. naccarii ((NAC AJ549114) A. oxyrinchus (OXY AF402894), A. gueldenstaedtii (GUE FJ392605), A. baerii (BAE AY544135), A. persicus (PER AY544139), A. nudiventris (NUD AY544138), H. huso (HUS AY544146), A. stellatus (STE AY544144), A. ruthenus (RUT AY544140), A. fulvescens (FUL AF402885), A. brevirostrum (BRE AF402886), A. transmontanus (TRA AF402893), A. sinensis (SIN AY544143), A. schrenckii (SCH AY544142), H. dauricus (DAU AY544147), A. mikadoi (MIK AY544141), A. medirostris (MED AF125598), S. platorynchus (PLA AF402901), S. albus (ALB AY430247) and S. suttkusii (SUS AF402900). The grey boxes show the diagnostic sites used in the analysis. The alignment does not show the primer sequence.

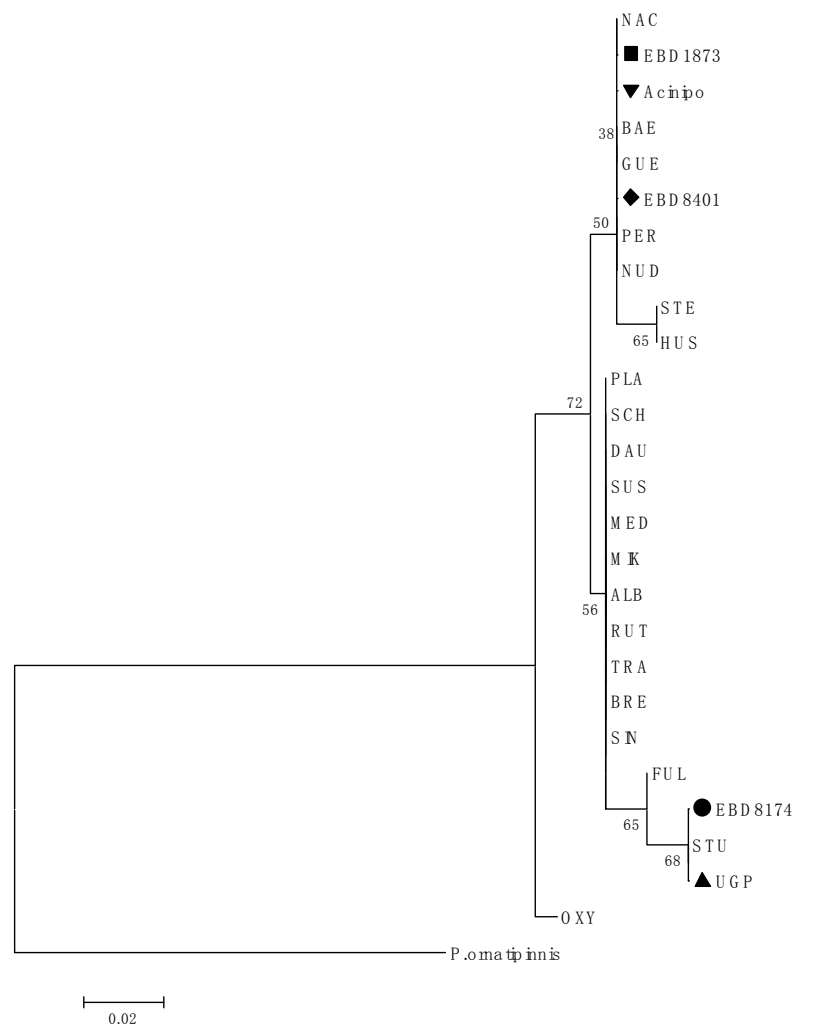

Figure 5. Neighbour-joining tree based on $12 \mathrm{~S}$ mitochondrial gene sequences. Neighbour-joining tree based on $12 \mathrm{~S}$ mitochondrial gene sequences and Jukes-Cantor distances calculated in MEGA 4. The tree shows the close relationships between sequences from Acinipo $(\boldsymbol{\nabla})$, EBD8173 and EBD8104 with $A$. naccarii and between sequences from UGP and EBD8174 with $A$. sturio. Numbers indicate the bootstrap support for each node (10000 replicates). Polypterus. ornatinnis (Bichir NC001778) is used as outgroup.

dalquivir River. Similarly, A. sturio was distributed not so long ago throughout Europe whereas, at the present, only one population exists, in the Gironde-GaronneDordogne River, France [41-44]. Furthermore, to propose a broad distribution area for A. naccarii is consistent with the general observation that most sturgeon species inhabited vast areas of continents and river basins [45]. Thus, observations based on molecular analyses, as we present in this paper, or the finding of an "American" species in Europe (i.e. the movement of A. oxyrinchus into Europe during the Little Middle Ages [46,47]), require more studies in order to establish a more complete vision of the distribution of different sturgeon species in Western Europe.

\section{ACKNOWLEDGEMENTS}

This research has been financed by grants of the Junta de Andalucía, Consejería de Innovación, Ciencia y Empresa (Proyecto de Investigación de Excelencia P07-CVI-03296) (F. Robles is a postdoctoral grant holder in this Project). Nerja Cave was analysed in the Project "Revisión, estudio y contextualización cronoestratigráfica de los restos arqueológicos procedentes de las antiguas excavaciones del Patronato de la Cueva de Nerja", authorized by Consejería de Cultura de la Junta de Andalucía to one of the authors (MCS). We also thank our colleague 
D. Nesbitt for revising our English text.

\section{REFERENCES}

[1] Carmona, R., Domezain, A., García-Gallego, M., Hermando, J.A., Rodríguez, F. and Ruiz-Rejón, M. (Ed.) (2009) Biology, Conservation and sustainable development of sturgeons, Fish \& Fisheries, Series 29, Springer.

[2] Garrido-Ramos, M.A., Soriguer, C., de la Herrán, R., Jamilena, M., Ruiz-Rejón, C., Domezain, A., Hernando, J.A. and Ruiz-Rejón, M. (1997) Morphometric and genetic analysis as proof of the existence of two sturgeon species in the Guadalquivir river. Marine Biology, 129(1), 33-39.

[3] De la Herrán, R., Martínez-Espín, E., Lorente, J.A., Ruiz-Rejón, C., Garrido-Ramos, M.A. and Ruiz-Rejón, M. (2004) Genetic identification of western Mediterranean sturgeons and its implication for conservation. Conservation Genetics, 5(4), 545-551.

[4] Garrido-Ramos, M.A., Robles, F., de la Herrán, R., Martínez-Espín, E., Lorente, J.A., Ruiz-Rejón, C. and Ruiz-Rejón, M. (2009) Analysis of mitochondrial and nuclear DNA markers in old museum sturgeons yield insights about the species existing in Western Europe: $A$. sturio, A. naccarii and A. oxyrinchus. In: Carmona, et al., Ed., Biology, Conservation and Sustainable Development of Sturgeons, Fish \& Fisheries, Series 29, Springer, 2549.

[5] Capello, F.B. (1869) Catalogo dos peixes do Portugal que existem do Museu de Lisboa. Jornal de Sciencias Mathematicas, Physicas, e Naturaes, 1(2), 131-193.

[6] Capello, F.B. (1880) Catalogo dos peixes do Portugal. Mémoires de l'Académie Royale des Sciences, Lisboa, 6 , $1-78$.

[7] Osório, B. (1894) D'algunas especies a juntar ao Catalogo dos peixes do Portugal de Capello. Jornal de Sciencias Mathematicas, Physicas, e Naturaes, 3(11), 186-188.

[8] Nobre, A. (1931) Peixes das aguas doces de Portugal. Boletim Ministério da Agricultura, 13(2), 73-112.

[9] Nobre, A. (1935) Fauna Marinha de Portugal. Vertebrados, Porto, 579.

[10] Gonçalves, B.C. (1942) Colecçao ocenográfica de D. Carlos I. Catálogo dos Peixes. Travaux Station de Biologie Marine de Lisbonne, 46, 1-108.

[11] Helling, H. (1943) Novo catalogo dos Peixes do Portugal em colecçao no Museu de Zoologia da Universidade de Coimbra. Memórias e Estudos do Museu Zoológico da Universidade de Coimbra, 149, 1-110.

[12] Albuquerque, R.M. (1956) Peixes do Portugal e ilhas adjacentes. Chaves para a sua determinação. Portugaliae Acta Biológica, 5B, 195.

[13] Bauchot, M.L. (1987) Poissons osseux. In: Fischer, W., Bauchot, M.L. and Schneider, M., Eds., Fiches FAO d'identification pour les besoins de la pêche (rev.1). Méditerranée et mer Noire. Zone de pêche 37, Commission des Communautés Européennes and FAO, Rome, 2, 891-1421.

[14] Rincón, P.A. (2000) Putative morphometric evidence of the presence of Acipenser naccarii Bonaparte, 1836 in
Iberian rivers, or why ontogenetic allometry needs adequate treatment. Boletín Instituto Español de Oceanografia, 16(1-4), 217-229.

[15] Almodóvar, A., Machordom, A. and Suárez, J. (2000) Preliminary results from characterization of the Iberian Peninsula sturgeon based on analysis of the mtDNA cytochrome b. Symposium on Conservation of the Atlantic Sturgeon Acipenser sturio. L., 1758 in Europe, Boletín. Instituto Español de Oceanografia, 16(1-4), 17-27.

[16] Gasent-Ramírez, J.M., Godoy, J.A. and Jordano, P. (2001) Identificación de esturiones procedentes del Guadalquivir mediante análisis de ADN en especimenes de museo. Publicaciones de la Consejería de medio Ambiente de la Junta de Andalucía, 36, 44-49.

[17] Ludwig, A., Arndt, U., Debus, L., Roselló, E. and Morales, A. (2009) Ancient mitochondrial DNA analyses of Iberian sturgeons. Journal Applied Ichthyology, 25(1), 5-9.

[18] Aguayo, P., Carrilero, M., Martínez, G., Afonso, J.A., Garrido, O. and Radial, B. (1989) Excavaciones Arqueológicas en el yacimiento de Ronda la Vieja (Acinipo). Campaña de 1988. Anuario Arqueológico de Andalucía 88/II, Consejería de Cultura, Junta de Andalucía, Sevilla, 309-314.

[19] Carrilero, M., Aguayo, P., Garrido, O. and Padial, B. (2002) Autóctonos y fenicios en la Andalucía Mediterránea. en XVI Jornadas de Arqueología fenicio-púnica (Eivissa, 2001), Treballs del Museu Arqueologic d' Eivissa i Formentera, Ibiza, 50, 69-125.

[20] Simón Vallejo, M.D. (2003) Una secuencia con mucha prehistoria: la Cueva de Nerja. Mainake, 25, 249-274.

[21] Cortés, M. (2004) Del Magdaleniense al Neolítico en la costa de Malaga. Novedades y perspectivas. Actas Jornadas Temáticas Andaluzas de Arqueología, Sociedades recolectoras y primeros productores, Junta de Andalucía, 109-122.

[22] Martínez-Espín, E., Martínez-González, L.J., Álvarez, J.C., Roby, R.K. and Lorente, J.A. (2009) Forensic strategies used for DNA extraction of ancient and degraded museum sturgeon specimens. In: Carmona, et al., Ed., Biology, Conservation and Sustainable Development of Sturgeons, Fish \& Fisheries, Series 29, Springer, 8596.

[23] Donoghue, H.D., Spigelman, M., Greenblatt, C.L., Lev-Maor, G., Bar-Gal, G.K., Matheson, C., Vernon, K., Nerlich, A.G. and Zink, A.R. (2004) Tuberculosis: From prehistory to Robert Koch, as revealed by ancient DNA. Lancet Infectious Diseases, 4(9), 584-592.

[24] Hagelberg, E. and Clegg, J.B. (1991) Isolation and characterization of DNA from archaeological bone. Proceedings of the Royal Society B: Biological Sciences, 244 (1309), 45-50.

[25] De la Herrán, R., Fontana, F., Lanfredi, M., Congiu, L., Leis, M., Rossi, R., Ruiz-Rejón, C., Ruiz-Rejón, M. and Garrido-Ramos, M.A. (2001) Slow rates of evolution and sequence homogenization in an ancient satellite DNA family of sturgeons. Molecular Biology and Evolution, 18(3), 432-436.

[26] Robles, F., De la Herrán, R., Ludwig, A., Ruiz-Rejón, C., Ruiz-Rejón, M. and Garrido-Ramos, M.A. (2004) Evolution of ancient satellite DNAs in sturgeon genomes. Gene, 338(1), 133-142. 
[27] Tagliavini, J., Williot, P., Congiu, L., Chicca, M., Lanfredi, M., Rossi, R. and Fontana, F. (1999) Molecular cytogenetic analysis of the karyotipe of the European Atlantic sturgeon, Acipenser sturio. Heredity, 83(5), 520525.

[28] King, T.L., Lubinski, B.A. and Spidle, A.P. (2001) Microsatellite DNA variation in Atlantic sturgeon (Acipenser oxyrinchus oxyrinchus) and cross-species amplification in the Acipenseridae. Conservation Genetics, 2(2), 103-119.

[29] Ludwig, A. and Kirschbaum, F. (1998) Comparison of mitochondrial DNA sequences between the European and the Adriatic sturgeon. Journal of Fish Biology, 52(6), 1289-1291.

[30] Ludwig, A., May, B., Debus, L. and Jenneckens, I. (2000) Heteroplasmy in the mtDNA control region of sturgeon (Acipenser, Huso and Scaphirhynchus). Genetics, 156(4), 1933-1947.

[31] Thompson, J.D., Gibson, T.J., Plewniak, F., Jeanmougin, F. and Higgins, D.G. (1997) The ClustalX windows interface: Flexible strategies for multiple sequence alignment aided by quality analysis tools. Nucleic Acids Research, 25(24), 4876-4882.

[32] Tamura, K., Dudley, J., Nei, M. and Kumar, S. (2007) MEGA4: Molecular Evolutionary Genetics Analysis (MEGA) software version 4.0. Molecular Biology and Evolution, 24(8), 1596-1599.

[33] Michener, D. and Sokal, R.R. (1957) A quantitative approach to a problem of classification. Evolution, 11(2), 130-162.

[34] Saitou, N. and Nei, M. (1987) The neighbor-joining method: A new method for reconstructing phylogenetic trees. Molecular Biology and Evolution, 4(4), 406-425.

[35] Fontana, F., Tagliavini, J. and Congiu, L. (2001) Sturgeon genetics and cytogenetics: Recent advancements and perspectives. Genetica, 111(1-3), 359-373.

[36] Arefjev, V.A. (1997) Cytogenetics of interploid hybridization of sturgeons. Proceedings of the 3rd International Symposium on Sturgeon, Piacenza, Italy, 277.

[37] Ludwig, A., Lippold, S., Debus, L. and Reinartz, R. (2009) First evidence of hybridization between endangered starlets (Acipenser ruthenus) and exotic Siberian sturgeons (Acipenser baerii) in the Danube River. Biological Invasions, 11, 753-760.

[38] Ludwig, A., Congiu, L., Pitra, C., Fickel, J., Gessner, J.,
Fontana, F., Patarnello, T. and Zane, L. (2003) Nonconcordant evolutionary history of maternal and paternal lineages in Adriatic sturgeon. Molecular Ecology, 12(12), 3253-3264.

[39] Tiedemann, R., Moll, K., Paulus, K.B., Scheer, M., Williot, P., Bartel, R., Gessner, J. and Kirschbaum, F. (2007) Atlantic sturgeons (Acipenser sturio, Acipenser oxyrinchus): American females successful in Europe. Naturwissenschaften, 94(3), 213-217.

[40] Pagès, M., Desse-Berset, N., Tougard, C., Brosse, L., Hänni, C. and Berebi, P. (2008) Historical presence of the sturgeon Acipenser sturio in the Rhône basin determined by the analysis of ancient DNA cytochrome b sequences. Conservation Genetics, 10(1), 217-224.

[41] Rochard, E., Castelnaud, G. and Lepage, M. (1990) Sturgeons (Pisces: Acipenseridae), threats and prospects. Journal of Fish Biology, 37(Suppl A), 123-132.

[42] Lepage, M. and Rochard, E. (1995) Threatened fishes of the world: Acipenser sturio Linnaeus, 1758 (Acipenseridae). Environmental Biology of Fishes, 43(1), 28.

[43] Williot, P., Rochard, E., Castelnaud, G., Rouault, T., Brun, R., Lepage, M. and Elie, P. (1997) Biological and ecological characteristics of European Atlantic sturgeon, Acipenser sturio, as foundations for a restoration programme in France. Environmental Biology of Fishes, 48 (1-4), 359-370.

[44] Williot, P., Arlati, G., Chebanov, M., Gulyas, T., Kasimov, R., Kirschbaum, F., Patriche, N., Pavlovskaya, L., Poliakova, L., Pourkazemi, M., Yu, K., Zhuang, P. and Zholdasova, I.M. (2002) Status and management of Eurasian sturgeon: An overview. International Review of Hydrobiology, 87(5-6), 483-506.

[45] Choudhury, A. and. Dick, T.A. (1998) The historical biogeography of sturgeons (Osteichthyes: Acipenseridae): A synthesis of phylogenetics, palaeontology and palaeogeography. Journal Biogeography, 25(4), 623-640.

[46] Ludwig, A., Debus, L., Lieckfeldt, D., Wirgin, I., Benecke, N., Jenneckens, I., Williot, P., Waldman, J.R. and Pitra, C. (2002) When the American sea sturgeon Swam east. Nature, 419(6906), 447-448.

[47] Ludwig, A., Arndt, U., Lippold, S., Benecke, N., Debus, L., King T.L. and Matsumura, S. (2008) Tracing the first steps of American sturgeon pioneers in Europe. $B M C$ Evolutionary Biology, 8(1), 221-252. 